\title{
Complications of decompressive craniectomy for traumatic brain injury
}

\author{
Shirley I. Stiver, M.D., Ph.D. \\ Department of Neurosurgical Surgery, School of Medicine; and The Brain and Spinal Injury Center, \\ University of California San Francisco, California
}

\begin{abstract}
Decompressive craniectomy is widely used to treat intracranial hypertension following traumatic brain injury (TBI). Two randomized trials are currently underway to further evaluate the effectiveness of decompressive craniectomy for TBI. Complications of this procedure have major ramifications on the risk-benefit balance in decisionmaking during evaluation of potential surgical candidates. To further evaluate the complications of decompressive craniectomy, a review of the literature was performed following a detailed search of PubMed between 1980 and 2009. The author restricted her study to literature pertaining to decompressive craniectomy for patients with TBI. An understanding of the pathophysiological events that accompany removal of a large piece of skull bone provides a foundation for understanding many of the complications associated with decompressive craniectomy. The author determined that decompressive craniectomy is not a simple, straightforward operation without adverse effects. Rather, numerous complications may arise, and they do so in a sequential fashion at specific time points following surgical decompression. Expansion of contusions, new subdural and epidural hematomas contralateral to the decompressed hemisphere, and external cerebral herniation typify the early perioperative complications of decompressive craniectomy for TBI. Within the 1st week following decompression, CSF circulation derangements manifest commonly as subdural hygromas. Paradoxical herniation following lumbar puncture in the setting of a large skull defect is a rare, potentially fatal complication that can be prevented and treated if recognized early. During the later phases of recovery, patients may develop a new cognitive, neurological, or psychological deficit termed syndrome of the trephined. In the longer term, a persistent vegetative state is the most devastating of outcomes of decompressive craniectomy. The risk of complications following decompressive craniectomy is weighed against the life-threatening circumstances under which this surgery is performed. Ongoing trials will define whether this balance supports surgical decompression as a first-line treatment for TBI. (DOI: 10.3171/2009.4.FOCUS0965)
\end{abstract}

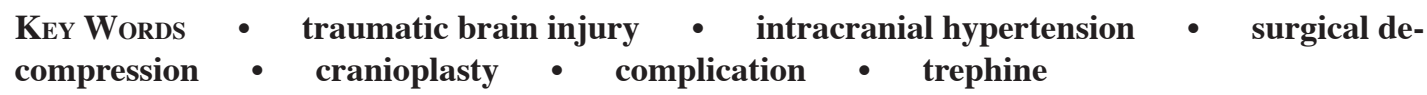

$\mathrm{T}$ wo randomized, multicenter prospective trials, RESCUEicp and DECRA, are currently in progress to determine whether decompressive craniectomy improves outcome in the management of TBI. ${ }^{14,37} \mathrm{Com}-$ plication rates of this procedure will be a major determinant of whether decompressive craniectomy proves superior to medical treatment for patients with intracranial hypertension after TBI. These procedures are performed for serious life-threatening intracranial hypertension, and mortality rates following decompressive craniectomy for severe TBI are high. During a 5-year experience with 170 consecutive decompressive hemicraniectomies for se-

Abbreviations used in this paper: $\mathrm{CBF}=$ cerebral blood flow; $\mathrm{EDH}=$ epidural hematoma; GCS = Glasgow Coma Scale; $\mathrm{ICP}=$ intracranial pressure; $\mathrm{RAP}=$ pressure-volume compensatory reserve; $\mathrm{SDH}=$ subdural hematoma; $\mathrm{TBI}=$ traumatic brain injury. vere TBI at our institution, $50 \%$ of patients died..$^{82}$ Many of the complications of decompressive craniectomy arise from the normal pathophysiological changes that occur in ICP, CSF circulation, and CBF following removal of a large area of skull bone.

The rationale behind decompressive craniectomy is to convert an injury within a closed box, with a fixed volume and limited reserve, into an open system with increased capacity to accommodate mass. ${ }^{64}$ After bone removal, there is an increase in brain compliance and a shift of the pressure volume curve to the right. ${ }^{29,33}$ The RAP index, determined as a correlation between fluctuations in ICP with heart rate against the mean ICP averaged over repetitive time points, is a surrogate for cerebral compliance. ${ }^{87}$ Improvements in RAP values as well as direct measurements using Spiegelberg compliance monitors have demonstrated improvements in cerebral 
TABLE 1: Literature summary of complications after decompressive craniectomy for TBI

\begin{tabular}{|c|c|c|c|c|c|c|c|c|c|}
\hline $\begin{array}{l}\text { Authors \& } \\
\quad \text { Year }\end{array}$ & $\begin{array}{c}\text { No. of } \\
\text { Patients }\end{array}$ & $\begin{array}{l}\text { Subdural } \\
\text { Hygroma }\end{array}$ & $\begin{array}{l}\text { Contusion/ } \\
\text { Hematoma } \\
\text { Progression }\end{array}$ & $\begin{array}{c}\text { Intra- } \\
\text { cranial } \\
\text { Infection }\end{array}$ & $\begin{array}{c}\text { New } \\
\text { Contralat } \\
\text { Extraaxial } \\
\text { Hematoma }\end{array}$ & $\begin{array}{l}\text { Hydro- } \\
\text { cephalus }\end{array}$ & $\begin{array}{l}\text { Bone } \\
\text { Flap Re- } \\
\text { sorption }\end{array}$ & $\begin{array}{l}\text { Reoperation } \\
\text { (excluding } \\
\text { cranioplasty) }\end{array}$ & Comment \\
\hline $\begin{array}{l}\text { Aarabi et } \\
\text { al., } 2006\end{array}$ & 50 & $25(50 \%)$ & $8(16 \%)$ & $\begin{array}{c}\text { wound } \\
\text { infection } \\
(1[2 \%])\end{array}$ & & $5(10 \%)$ & $6(12 \%)$ & & $\begin{array}{l}6(12 \%) \text { developed paren- } \\
\text { chymal lucency possibly } \\
\text { related to ischemia; bone } \\
\text { flap infection after cranio- } \\
\text { plasty (in 3) }\end{array}$ \\
\hline $\begin{array}{l}\text { Chibbaro } \\
\text { and Tac- } \\
\text { coni, } \\
2007\end{array}$ & 48 & & $3(6 \%)$ & $1(2 \%)$ & & $1(2 \%)$ & & & \\
\hline $\begin{array}{l}\text { Flint et al., } \\
2008\end{array}$ & 40 & & 23 (58\%) & & $11(28 \%)$ & & & & $\begin{array}{l}12 / 40(30 \%) \text { new or wors- } \\
\text { ened IVH }\end{array}$ \\
\hline $\begin{array}{l}\text { Gaab et } \\
\text { al., } 1990\end{array}$ & $\begin{array}{c}37 \text { (18 } \\
\text { unilat, } \\
19 \text { bilat) }\end{array}$ & 13 (22\%) & & & & $\begin{array}{l}5(13 \%) \\
\text { shunt- } \\
\text { treated }\end{array}$ & & & \\
\hline $\begin{array}{l}\text { Guerra et } \\
\text { al., } 1999\end{array}$ & $\begin{array}{c}57 \text { (31 } \\
\text { unilat, } \\
26 \text { bilat) }\end{array}$ & $15(26 \%)$ & & & & $8(14 \%)$ & & & $\begin{array}{l}1(2 \%) \text { wound infection after } \\
\text { cranioplasty }\end{array}$ \\
\hline $\begin{array}{l}\text { Huang et } \\
\text { al., } 2008\end{array}$ & 38 & 10 (26\%) & $2(5 \%)$ & $2(5 \%)$ & & $3(8 \%)$ & & $3(8 \%)$ & \\
\hline $\begin{array}{l}\text { Jiang et } \\
\text { al., } 2005\end{array}$ & 241 & $38(16 \%)$ & & $8(3 \%)$ & & & & & $\begin{array}{l}\text { incisional CSF fistula (3\%); } \\
\text { epilepsy (3\%) }\end{array}$ \\
\hline $\begin{array}{l}\text { Polin et } \\
\text { al., } 1997\end{array}$ & 35 & & $\begin{array}{c}2(6 \%)(1 \\
\text { required } \\
\text { reop) }\end{array}$ & $1(3 \%)$ & & $\begin{array}{c}10(29 \%) \\
\text { shunt- } \\
\text { treated }\end{array}$ & $2(6 \%)$ & $\begin{array}{l}1(3 \%) \text { reop for } \\
\text { delayed expansion } \\
\text { of a temporal con- } \\
\text { tusion requiring } \\
\text { lobectomy }\end{array}$ & $\begin{array}{l}1 \text { CSF leak treated w/ } \\
\text { lumbar drain }\end{array}$ \\
\hline $\begin{array}{l}\text { Yang et } \\
\text { al., } 2003\end{array}$ & 68 & 18 (26\%) & & $4(6 \%)$ & & $20(29 \%)$ & & & \\
\hline $\begin{array}{l}\text { Yang et } \\
\text { al., } 2008\end{array}$ & 108 & & & & $\begin{array}{l}7(6 \%) \text { w/ } \\
\text { reop }\end{array}$ & $\begin{array}{l}9(8 \%) \\
\text { shunt- } \\
\text { treated }\end{array}$ & & $\begin{array}{l}19(18 \%) \text { : contralat } \\
\text { intracranial hema- } \\
\text { toma }(7[6 \%]) \text {, sub- } \\
\text { dural effusion (3 } \\
\text { [3\%]), hydrocepha- } \\
\text { lus (9 [8\%]) }\end{array}$ & \\
\hline
\end{tabular}

compliance following decompressive craniectomy. ${ }^{2,87}$ As a rescue therapy, decompressive craniectomy has been shown to reliably abort progressive increases in ICP. ${ }^{59,89}$ Decompressive craniectomy also brings about changes

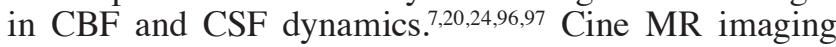
studies have demonstrated impaired CSF flow across the craniovertebral junction at the skull base, which improves following cranioplasty repair of the skull defect. ${ }^{20}$ Decompressive craniectomy also induces a hyperemic response as evidenced by ${ }^{99 \mathrm{~m} T c}$ SPECT, ${ }^{31} \mathrm{P}$ MR imaging, and ${ }^{133} \mathrm{Xe}$ CT studies demonstrating augmentation of $\mathrm{CBF}$ as well as cerebral metabolism. ${ }^{96,101}$ Physiological monitoring using $\mathrm{CBF}$, transcranial Doppler, and brain tissue oxygen probes has demonstrated increased $\mathrm{CBF}$ and brain tissue oxygen following decompressive craniectomy. ${ }^{7,39,80}$ Cerebrovascular reactivity is also impaired for the first 24 hours, trending toward a return to intact autoregulation within the first
72 hours following decompressive craniectomy. Measurements of PRx, the correlation coefficient of ICP versus arterial blood pressure over repetitive time intervals, have shown increases indicative of loss of cerebrovascular reactivity after decompression..$^{89,94}$ Loss of autoregulation in the early period following decompressive craniectomy may derive from a state of maximal vasodilation and hyperemia following relief of prolonged severe compression.,71 These alterations in compliance, CBF and autoregulation, and CSF circulation are the basis for many of the complications that arise following decompressive craniectomy.

\section{Overview and Risks for Complications}

Complications following decompressive craniectomy occur at predictable time points following the surgery. They can often be anticipated and in many cases prevent- 

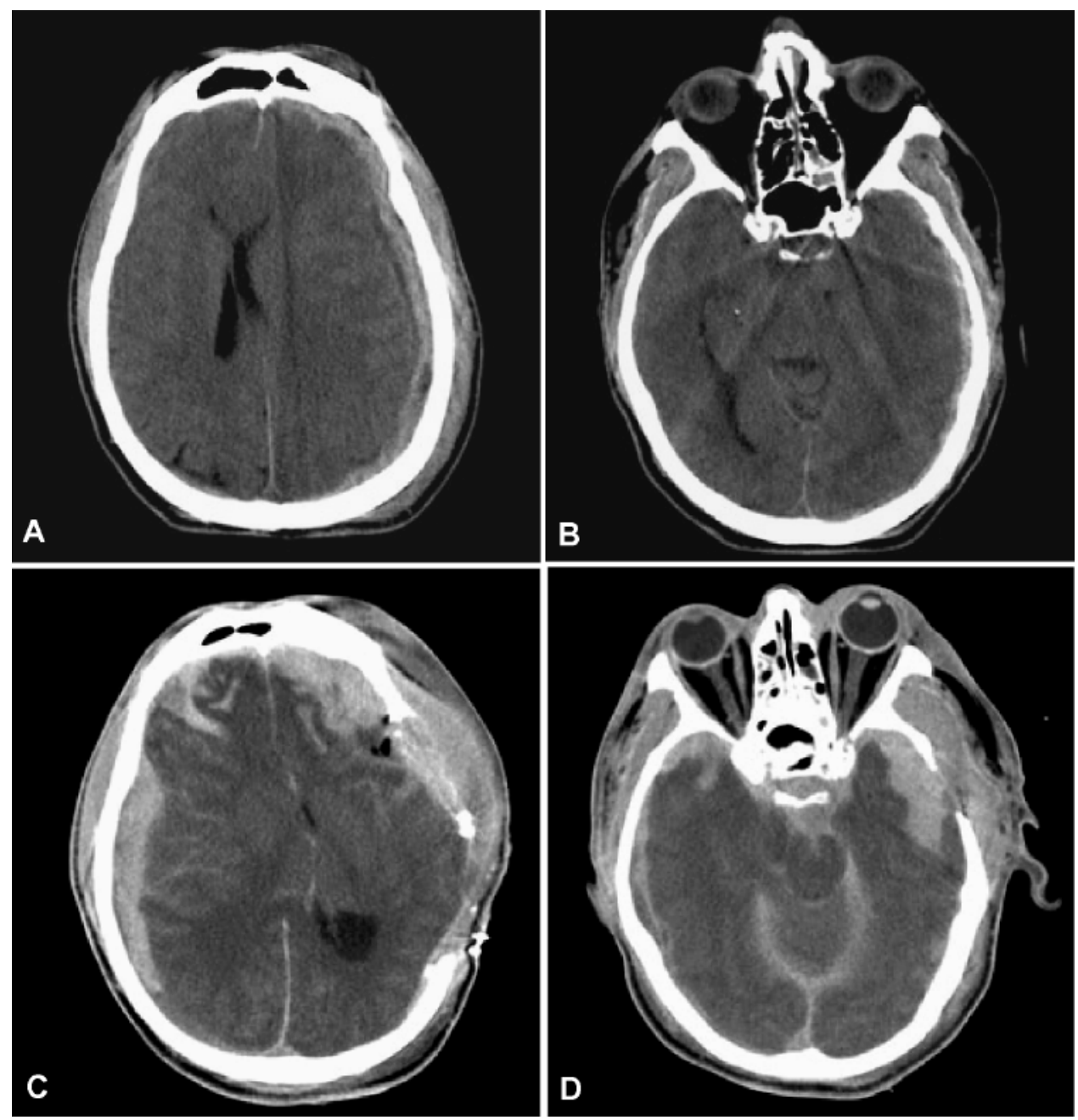

FIG. 1. Coagulopathy. Preoperative noncontrast CT scans of an SDH in a patient on a regimen of warfarin (A and B). Despite reversal of the coagulopathy before surgery, marked hemorrhagic blossoming occurred as evidenced by postoperative noncontrast images ( $\mathrm{C}$ and $\mathrm{D})$. Note in panel $\mathrm{C}$ the development of an extraaxial SDH contralateral to the decompressed hemisphere.

ed. Bleeding may be initiated during bone decompression and this, as well as development of new or expanded contusions, may present with malignant swelling or elevations in ICP in the first few hours or days after decompression. In a decompressed skull, even an ICP of 20 $\mathrm{mm} \mathrm{Hg}$ may be of concern. External cerebral herniation frequently evolves over the first few days following decompressive surgery and can be problematic if the bone decompression is not sufficiently large to allow the brain to expand without constriction. In the early postoperative period $(<1$ week), manifestations of deranged CSF flow become evident with evolution of subdural hygromas. Fevers are common during this time, and the need for lumbar puncture for CSF sampling needs to be weighed carefully against the risks of inducing a paradoxical herniation syndrome. Wound infections are common. In the late postoperative period, unique complications of decompressive craniectomy include those of syndrome of the trephined.

Patients with severe TBI are at increased risk of developing complications after decompressive craniectomy (Table 1). ${ }^{99}$ In patients having sustained TBI, Yang et al. ${ }^{99}$ reported that the frequency of complications was $62 \%$ for GCS Scores 3-5, 39\% for GCS Scores 6-9, and 36\% for GCS scores $>9$. Older patients ( $>60$ years) also tended to have more complications, but the differences compared with younger patients were not statistically significant. ${ }^{99}$ Patients taking aspirin, Plavix, and warfarin are at particularly high risk for severe or nonsurvivable complications following decompressive craniectomy (Fig. 1).

\section{Complications}

\section{Perioperative Complications}

Blossoming of Contusions. Hemorrhagic expansion of contusions is inherent in the injury process and has been demonstrated on serial CT scanning in patients with TBI. ${ }^{10,58,79}$ Hemorrhagic contusion expansion was observed in $42 \%$ of 142 TBI patients with median GCS scores of $8,{ }^{58} 59 \%$ of 37 patients in a coma, ${ }^{77} 48 \%$ of 104 children with TBI, ${ }^{28}$ and $47 \%$ of 141 patients with TBI presenting with traumatic subarachnoid hemorrhage on their CT 

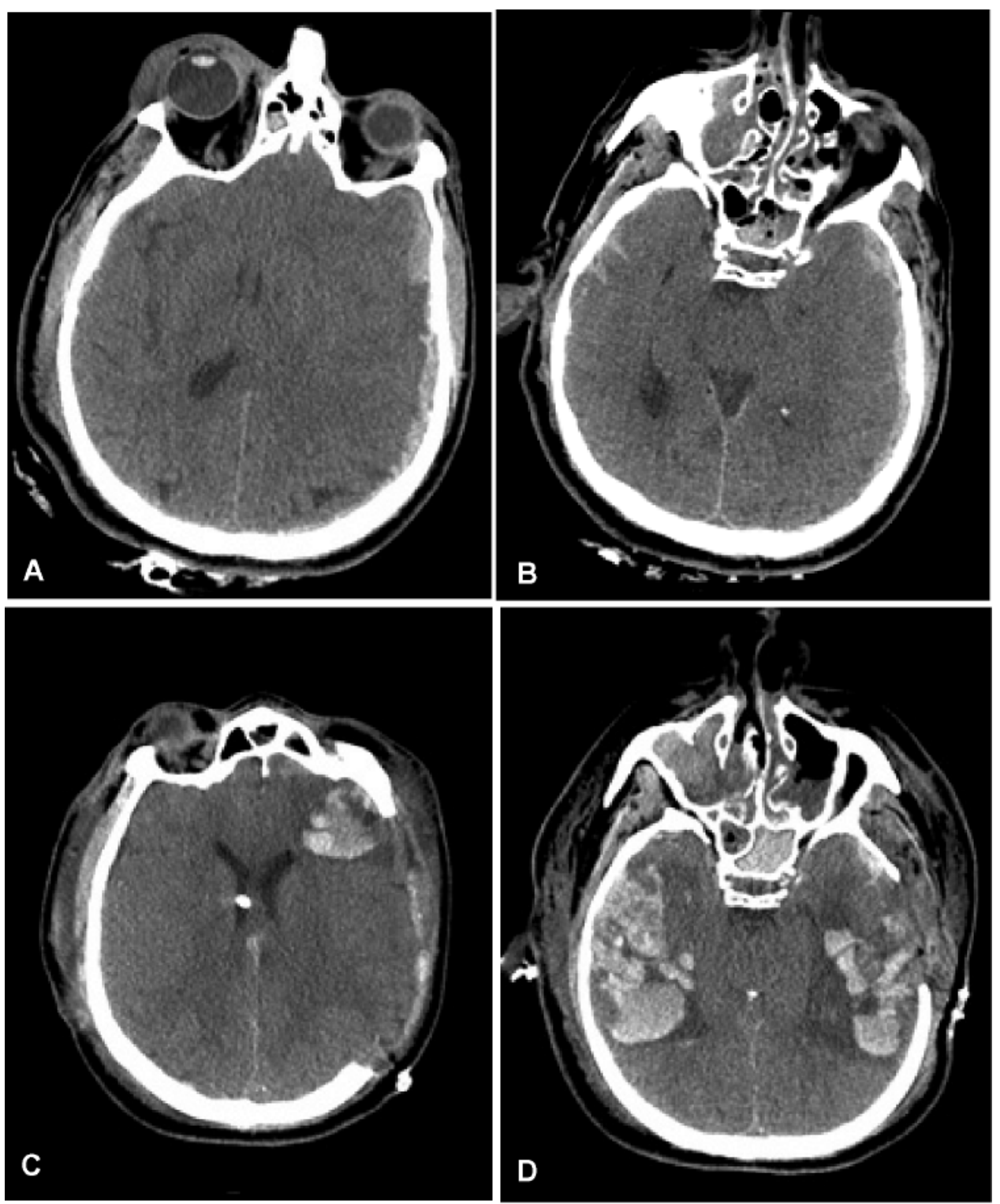

FIG. 2. Contusion blossoming. Preoperative (A and $B)$ and postoperative $(C$ and $D)$ noncontrast $C T$ images demonstrating massive temporal contusions following decompressive craniectomy. Note the relative absence of parenchymal lesion burden in the temporal lobes on the preoperative images.

scan. ${ }^{12}$ Experimental animal models of controlled cortical impact have demonstrated that craniectomy, compared with craniotomy, reduces contusion volume by $40 \% .{ }^{102}$ In contrast, relief of the tamponade effect with bone removal in patients with severe TBI may facilitate growth and expansion of contusions following decompressive craniectomy. ${ }^{23,49}$ In a CT imaging study of contusions pre- and post-decompressive craniectomy, Flint et al. ${ }^{23}$ found a remarkably high incidence of new or expanded hemorrhagic contusions following decompressive surgery (Fig. 2). In that study, the authors defined nonhemorrhagic contusions as areas of hypodensity on CT scans with focal stippling of blood but without a hematoma that could be measured. By contrast, hemorrhagic contusions were defined as contusions associated with a measurable hematoma. Following decompressive craniectomy, new or expanded hemorrhagic contusions were observed in $23(58 \%)$ of 40 patients. The evolving contusion was ipsilateral to the decompressed hemisphere in $82 \%$ of cases. Severity of the head injury as judged by the Rotterdam score ${ }^{48}$ of the initial CT scan correlated with the risk of hemorrhagic contusion expansion. Patients with Rotterdam scores of 5 or 6 had an $80 \%$ chance of expansion of their hemorrhagic contusions following decompressive craniectomy. The frequency and the total volume increase of the hemorrhagic contusion correlated with the Rotterdam score. In addition, there was a $30 \%$ (12 of 40) incidence of new or worsened IVH and a $28 \%$ (11 of 40) incidence of new or worsened extraaxial subdural or epidural hemorrhage. Hemorrhagic contusion volume was observed to correlate with outcome. Using a cutoff of $20 \mathrm{ml}$ determined from a receiver operator curve analysis, $8(57 \%)$ of 14 patients 

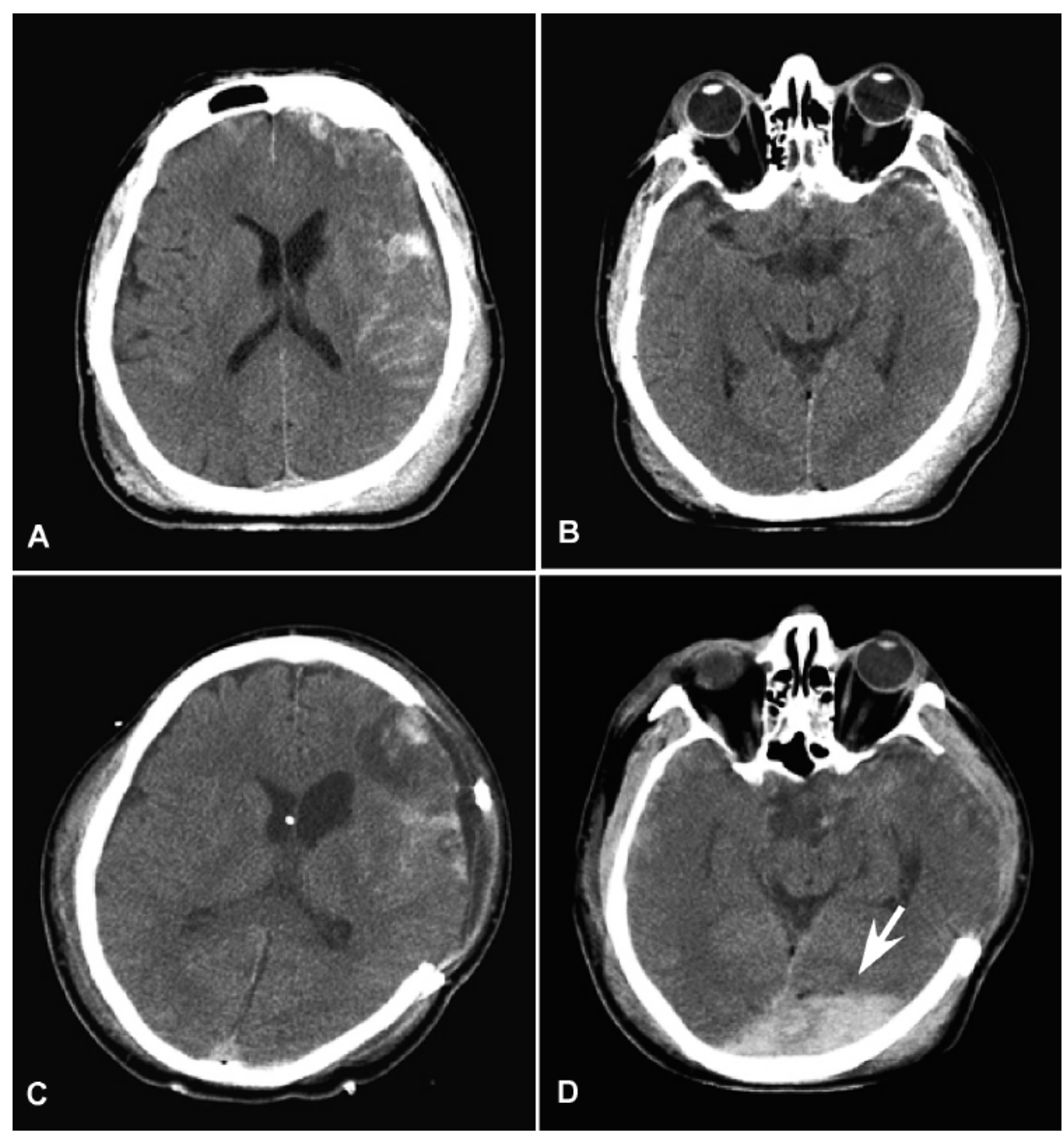

FIG. 3. Evolution of remote extraaxial hemorrhage. A and B: Preoperative noncontrast CT scans obtained in a patient with traumatic subarachnoid hemorrhage and a small SDH who underwent decompressive craniectomy. C and D: Postoperative noncontrast CT scans showing evolution of an occipital EDH (arrow), remote from the site of surgery. The patient underwent an occipital craniotomy and evacuation of the EDH. At surgery a linear, nondisplaced skull fracture was found overlying the occipital $\mathrm{EDH}$. A retrospective review of this patient's CT scan suggested that the fracture was parallel to the cuts of the CT image and the density of the occipital bone had masked detection of the fracture on the scout CT image.

with an expanded hemorrhagic contusion volume $>20 \mathrm{ml}$ died within 6 months, whereas only $4(15 \%)$ of 26 patients with contusion volumes $<20 \mathrm{ml}(\mathrm{p}=0.011)$ died. ${ }^{23}$

Evolution of Contralateral Mass Lesion. Surgical craniectomy decompression for TBI may incite a new mass lesion, contralateral or remote to the decompressed hemisphere ${ }^{13,52,63}$ (Fig. 3). Reduction in ICP after decompression likely plays an important role. ${ }^{8,43,86}$ Piepmeier and Wagner, ${ }^{63}$ however, have pointed out that if tamponade relief underlies contralateral bleeding, then one would expect delayed EDH lesions more frequently. High Rotterdam scores of initial CT scans have been observed to correlate with the development of contralateral extraaxial hemorrhages. ${ }^{23} \mathrm{Su}$ et al. ${ }^{84}$ observed 14 new contralateral EDHs following surgical evacuation of acute SDHs. In 10 of these patients, the EDH manifested with intraoperative brain swelling and external cerebral herniation during the acute subdural evacuation, necessitating that the bone flap not be replaced. Yang et al. ${ }^{99}$ reported a $7 \%$ incidence of new contralateral hematomas. Over half occurred within the first 24 hours after decompressive surgery. Detection of a fracture on CT scanning should increase awareness of this potential intraoperative or postoperative complication. In the study by Su et al., ${ }^{84}$ a fracture was found on CT scans in 10 (71\%) of 14 patients with new contralateral EDHs. A skull fracture was identified at surgery in each of the 12 patients treated by reoperation for evacuation of the EDH. The EDH localized to the site of the fracture in all cases. ${ }^{84}$

Theoretically patients may be at higher risk for developing a contralateral EDH following decompressive craniectomy than following craniotomy. Decompressive surgery may relieve the tamponade effect on a contralateral bleeding site and predispose the patient to an EDH. ${ }^{8,86}$ In general, the severity of the underlying TBI most strongly determines prognosis. Prompt awareness 

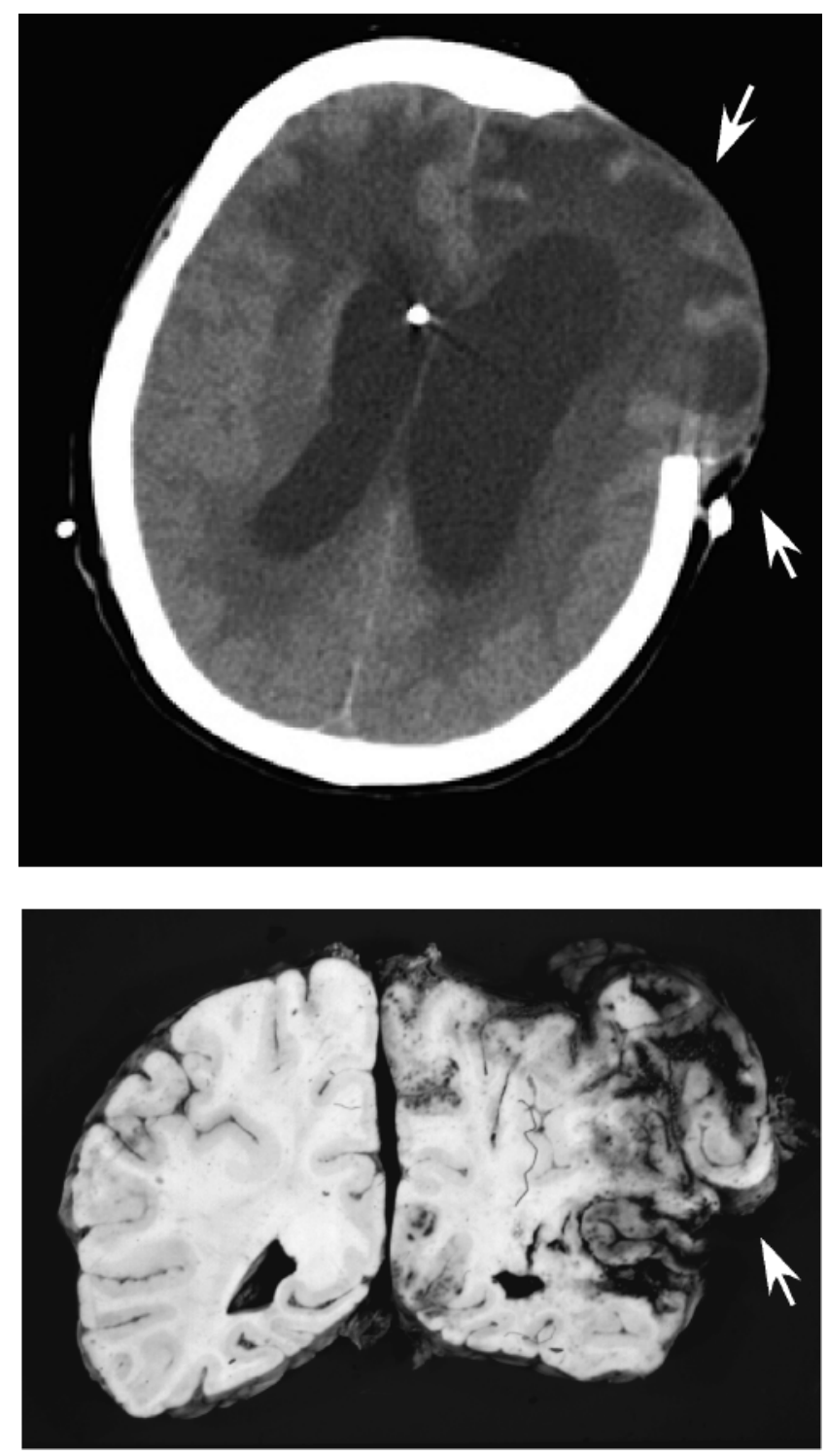

FIG. 4. External cerebral herniation. Upper: Noncontrast CT image demonstrating external cerebral herniation (arrows) through a small craniectomy. Lower: Photograph of a gross specimen obtained at autopsy in a different patient demonstrating external cerebral herniation (arrow) and venous infarction within the herniated brain tissue.

and evacuation of the delayed EDH may not impair recovery as long as the mass effect has not progressed to the stage of impairing brainstem function. ${ }^{84}$

External Cerebral Herniation. Expansion of the brain with external cerebral herniation through the craniectomy defect is often observed in the early period after decompression (Fig. 4). There is no consensus on how to measure external cerebral herniation. In the study by Yang et al., ${ }^{99}$ herniation through the craniectomy defect was measured at the middle of the cranial defect. Herniation was defined as brain tissue in the center of the bone defect $>$ $1.5 \mathrm{~cm}$ above the plane where the outer table of the cranium would normally lie. ${ }^{99}$ Using this measure, external cerebral herniation was observed in $28(26 \%)$ of 108 decompressive craniectomies. In contrast, Flint et al. ${ }^{23}$ mea-

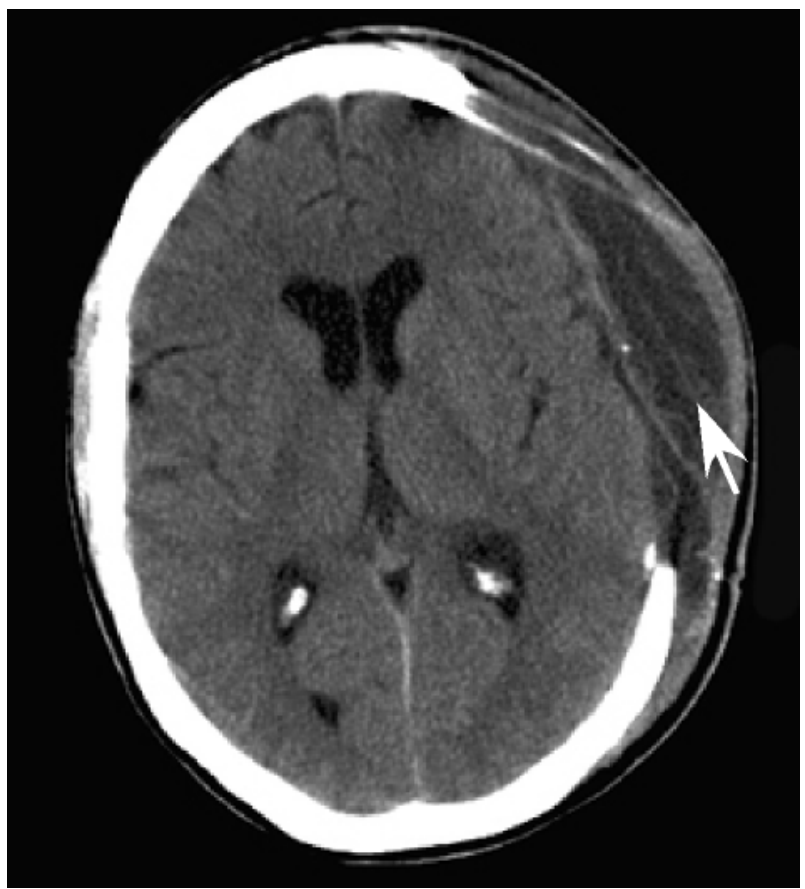

FIG. 5. Subdural hygroma. Noncontrast CT image of a subdural hygroma (arrow) following decompressive craniectomy.

sured extracranial cerebral herniation as the diameter of brain extending beyond a straight line drawn between the outer table edges of the craniectomy defect. In their series of decompressive craniectomies, the mean bone opening diameter was $13.9 \pm 1.2 \mathrm{~cm}$, and the mean diameter of external cerebral herniation was $2.1 \pm 0.9 \mathrm{~cm} .{ }^{23}$

Increased brain swelling is common in the 1 st week following decompressive craniectomy. The brain swelling may correspond to hyperperfusion, as detected by CT perfusion imaging. ${ }^{96}$ In addition, loss of resistance in brain tissue lacking a protective skull invokes a higher hydrostatic pressure gradient that may permit transcapillary leakage of edema fluid. ${ }^{59}$ Brain edema following decompressive craniectomy has been modeled in animal studies of injury using Evans blue dye extravasation. 15,25,69 Cooper et al. ${ }^{15}$ found a 7 -fold increase in edema formation as determined by Evans blue dye extravasation following craniectomy. Evidence of increased brain edema following craniectomy has not been verified in humans. ${ }^{70}$

Potential adverse effects of external cerebral herniation include compression of cortical veins within the herniated segment of brain and subsequent venous infarction of the herniated tissue. Small bone openings can lead to a mushroom cap-like appearance to brain that has herniated through the open defect (Fig. 4). ${ }^{59}$ Large bone decompression allows the brain to expand outward without constriction and minimizes the risk of venous ischemia. A technique of inserting "vascular cushions" adjacent to large draining veins at the craniectomy margin has been reported to reduce the risk of venous ischemia. ${ }^{17}$

\section{Postoperative Complications Within 30 Days}

Subdural Effusions or Hygromas. Decompressive 

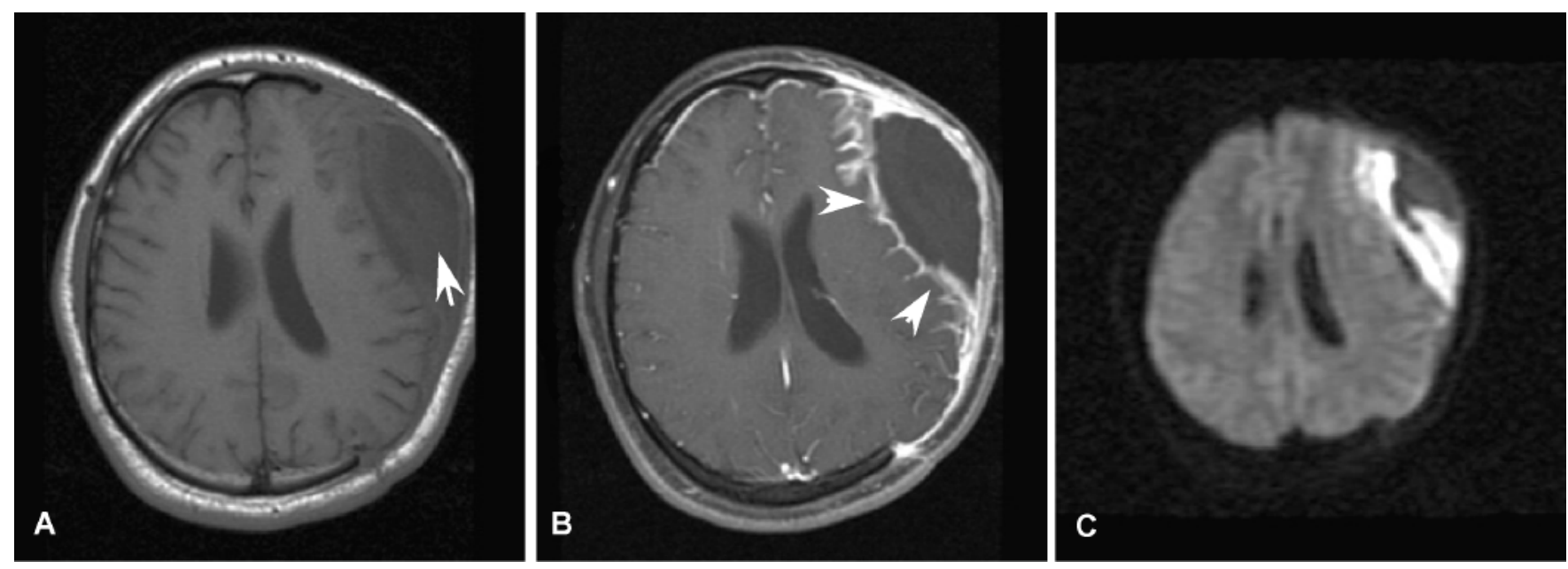

FIG. 6. Extraaxial empyema. A: A T1-weighted MR image showing a subdural collection (arrow). B: A T1-weighted Gdenhanced MR image demonstrating rim enhancement (arrowheads) of the collection. C: Diffusion weighted image with bright signal that is diagnostic of a subdural empyema.

craniectomy alters the dynamics of CSF circulation., ${ }^{9,100}$ This may exacerbate the occurrence of subdural hygromas and hydrocephalus. Subdural hygromas develop early after decompressive surgery (Fig. 5). In the study by Aarabi et al., ${ }^{1}$ subdural hygromas developed in 25 (50\%) of 50 patients after a mean of 8 days following decompressive craniectomy. Hygromas are generally ipsilateral to the skull defect with volumes ranging from 10 to 120 $\mathrm{ml}$ (mean $51 \mathrm{ml}) .{ }^{1}$ While most authors favor a mechanism of altered CSF dynamics to account for the occurrence of hygromas, others have suggested that increased cerebral perfusion pressure that accompanies decompressive craniectomy may play a role. ${ }^{45}$

Duraplasty at the time of decompression has been observed to lower the incidence of subdural effusions. ${ }^{100}$ Wrapping the cranium after the peak time of cerebral swelling has also been suggested to help prevent effusions. ${ }^{99}$ In the early experience of decompressive craniectomy, Guerra et al. ${ }^{32}$ reported that $10(67 \%)$ of 15 patients who developed hygromas responded to puncture treatment and only 5 (33\%) required a ventriculo- or lumboperitoneal shunt. In this report, $8(14 \%)$ of the 57 patients developed hydrocephalus. At our institution we avoid tapping into CSF hygromas and have found that most resolve spontaneously without need for intervention. Yang et al. ${ }^{99}$ reported a $21 \%$ incidence of subdural hygromas in their series and noted that 20 of 23 effusions resolved spontaneously without neurological deficits. Aarabi et al. ${ }^{1}$ have also shown that subdural hygromas following decompressive craniectomy regress spontaneously over weeks to months. In their series, no patient required decompression or shunt treatment of a hygroma collection. ${ }^{1}$ Two of the 25 patients, however, went on to develop delayed hydrocephalus.

Paradoxical Herniation. Paradoxical herniation with compression of the brainstem and neurological deterioration may present in a delayed fashion after a lumbar puncture in patients with decompressive craniectomy. ${ }^{93}$ Vile$1 \mathrm{a}^{93}$ described a case of a patient with a decompressive craniectomy whose condition suddenly deteriorated 38 days after a lumbar puncture to rule out meningitis. The precipitous deterioration was attributed to upright positioning with mobilization of the patient as she started to participate in rehabilitation therapy. Mobilization into the upright position may have invoked a higher cranial-spinal pressure gradient and perhaps even opened up a preexisting small dural hole from the lumbar puncture site. Neurological deterioration after lumbar puncture or lumbar CSF drainage in the setting of large cranial defects has also been observed following decompressive craniectomy for stroke. ${ }^{21,61}$ In the early period of recovery from traumatic injury following decompressive craniectomy, symptoms of paradoxical herniation may be masked and even mistaken for neurological damage from the trauma.

The concept that a negative pressure gradient between the cranial and spinal compartments, provoked by a spinal CSF leak, can precipitate downward herniation, even in the absence of raised ICP, has been carefully documented by many groups..$^{5,6,42,72,73}$ With a large skull defect, a lumbar puncture exacerbates the negative pressure gradient between the atmosphere and the cranium. ${ }^{93}$ Based on this, we have adopted a high threshold for performing lumbar puncture in patients with a decompressive craniectomy. Treatment for symptomatic herniation following lumbar puncture with a skull defect is the antithesis of that used for herniation in the setting of raised ICP, hence the term paradoxical herniation. Patients with paradoxical herniation should be treated with intravenous fluids, Trendelenburg positioning, and clamping of CSF drainage; hyperosmolar therapy should be discontinued, and early attention given to insertion of a blood patch. ${ }^{61,76,93}$ Cranioplasty may act to reduce the negative pressure gradient and should also be considered in the management of paradoxical herniation..$^{76,93}$

\section{Delayed Complications After 1 Month}

Wound Healing and Infection. There are several factors associated with decompressive craniectomy that 

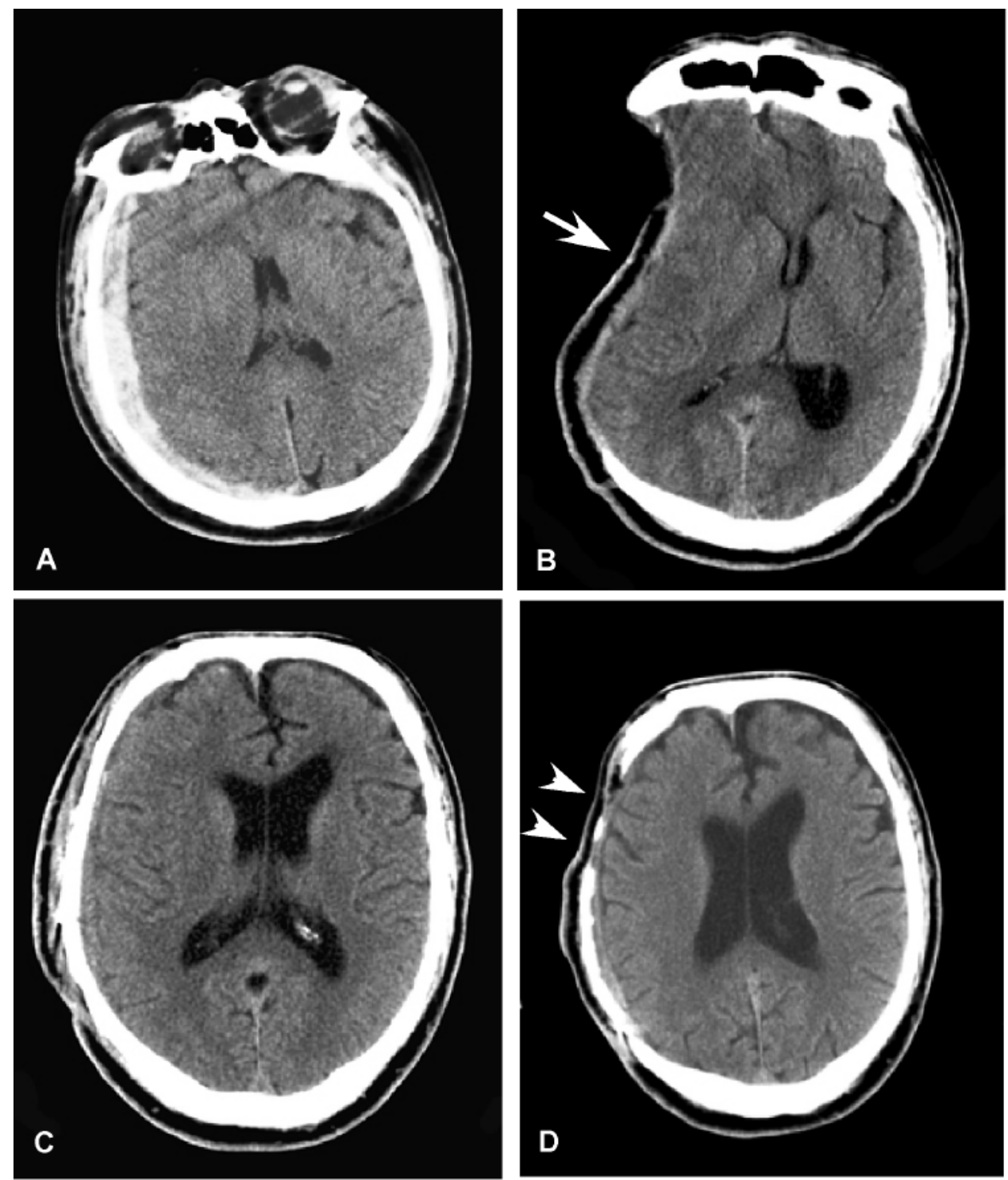

FIG. 7. Sinking scalp flap. A: Preoperative noncontrast CT scan demonstrating a right acute SDH, which was evacuated and the bone left off as a prophylactic measure against subsequent intracranial hypertension. B: A CT scan without contrast obtained several months later demonstrates a sunken parenchymal contour (arrow) with $\sim 1.5 \mathrm{~cm}$ of midline shift. C: After autologous cranioplasty repair of the skull defect, a CT scan showed restoration of both the sunken brain contour and the midline shift. D: Within 2 months following cranioplasty, noncontrast CT imaging began to show signs of partial resorption (arrowheads) of the replaced bone flap.

should lead one to expect a higher rate of infection than with standard craniotomy for general neurosurgical procedures. The incision varies but the typical, large, reverse question mark incision with a long scalp pedicle on a comparatively small base predisposes to wound breakdown along the parietal and posterior temporal limbs farthest along the flap. Bone removal is needed low in the temporal fossa to decompress the basal cisterns. To expose the scalp and temporalis muscle down to the level of the zygoma, the incision is carried to $1 \mathrm{~cm}$ below the zygoma anterior to the tragus. The urgency to decompress may not facilitate careful dissection and preservation of the superficial temporal artery. Sacrifice of the artery may impair perfusion of the scalp pedicle and negatively impact wound healing. The dura is not closed primarily.
Duraplasty using a dura substitute is associated with an increased risk of infection. ${ }^{50}$ If the dura is left open without duraplasty, a foreign synthetic material should be laid over the brain surface to prevent adherence of the scalp to the underlying brain. With the large bone flaps used for decompression, opening into the frontal sinus or air cells low in the middle fossa risks delayed meningitis and subdural empyema, especially if a duraplasty is not performed. Last, surgical fields in trauma surgery are often clean contaminated. The bone, soft tissues, and brain are easily contaminated by penetrating injury.

In the intensive care unit, fevers are common. We avoid tapping subdural collections and prefer to use contrast enhancement on CT and MR imaging together with diffusion weighted MR imaging to diagnose infected 

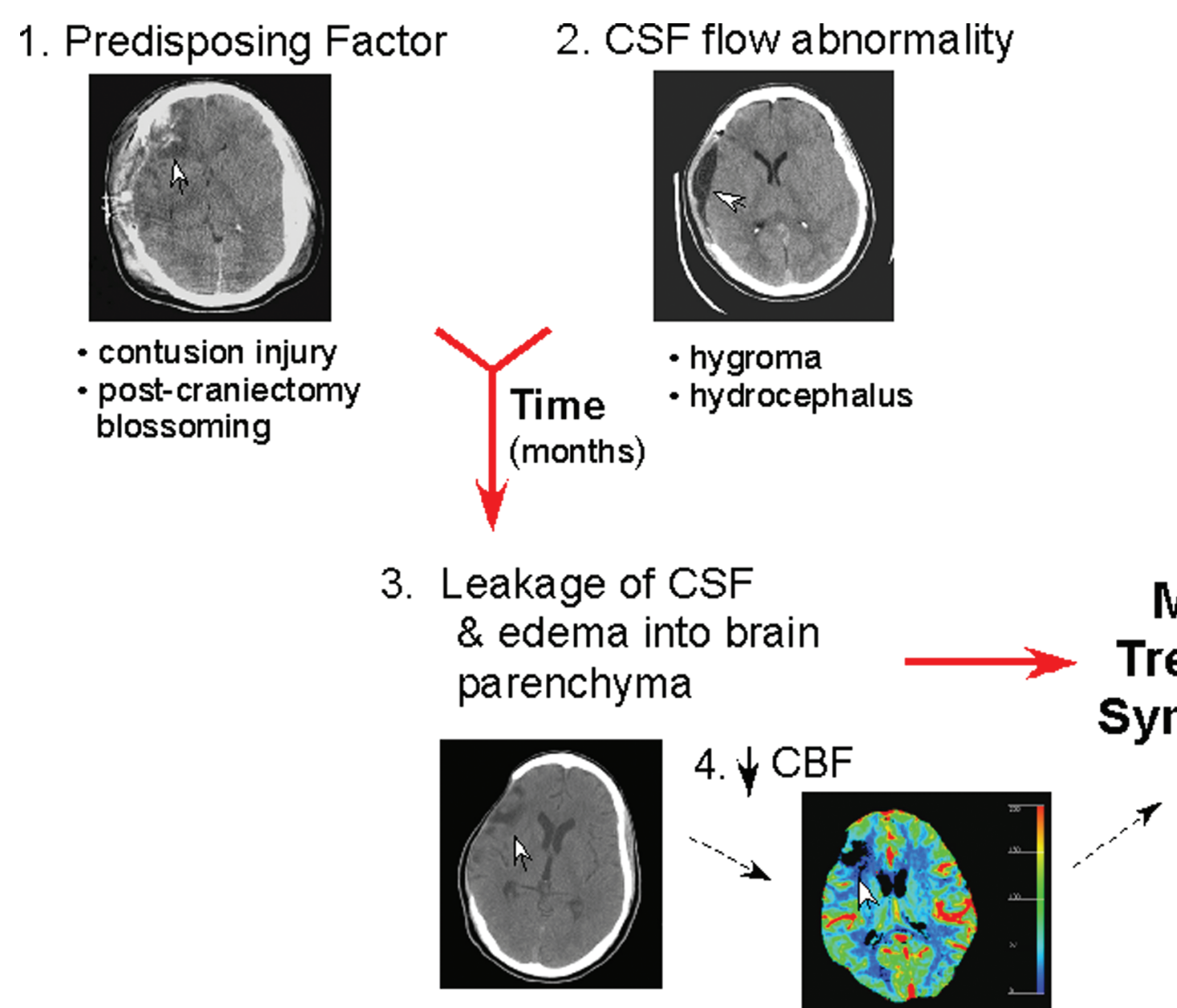

FIG. 8. Mechanistic schematic for motor trephine syndrome. The presence of prior intraparenchymal contusions as well as CSF flow abnormalities are requisite factors; neither alone is sufficient to induce the syndrome. 1) Contusions may be caused by the injury itself or blossoming following decompression (arrow). 2) The CSF hygromas (arrow) are present on early postoperative CT imaging in $90 \%$ of patients who develop motor trephine syndrome. Over time, dysfunction of CSF flow persists and reserve mechanisms decompensate. Long intervals to cranioplasty repair increase the likelihood of developing the syndrome. 3) The CSF and edema transgress into brain parenchyma underlying the skull defect, manifested by areas of hypoattenuation on CT imaging (arrow). Previous intraparenchymal contusion injury, decreased resistance to fluid accumulation in the absence of bone enclosure, and long intervals to cranioplasty facilitate transgression of CSF and edema into brain parenchyma underlying the craniectomy defect. 4) The CBF flow by CT perfusion imaging is diminished in areas of hypoattenuation (arrow) corresponding to CSF and edema leakage. Transgression of CSF and edema, acting through or in concert with diminished CBF leads to motor trephine syndrome. Reprinted from Stiver SI et al: Acta Neurosurg Suppl 102:273-277, 2008.

subdural collections (Fig. 6). In many cases, a superficial wound infection aids in the diagnosis of the underlying intracranial problem.

Decompressive craniectomy necessitates a second cranioplasty surgery to replace the bone. Repeat surgery inherently increases risks of infection. In our patient population, we and others have observed high rates of infection following early cranioplasty repair and prefer to wait a minimum of 3 months and generally longer, before replacing the bone. ${ }^{90}$ Storage of the bone for prolonged periods in a freezer also increases the risk of infection. ${ }^{60,67,90}$ To minimize risks of infection through opening of communications to the frontal sinus, we do not remove scar tissue from the area of the frontal sinus during exposure of the craniectomy margins for replacement of the bone flap.

Adhesions between the brain and scalp may be a source of neurological injury during subsequent exposure of the brain for the cranioplasty. If a duraplasty is not performed, it is important that the Gelfilm (Upjohn) or another dural substitute cover all aspects of exposed brain to prevent adhesion between the brain surface and the overlying scalp. The disadvantage of Gelfilm is that it appears to take several months for the pseudodura layer to form and completely seal a barrier layer overlying the brain. Duraplasty up front may enable an earlier cranioplasty repair. A recent report has advocated the use of DuraGen (Integra LifeSciences Corp.) that is laid over the brain without suture closure. Over time the Duragen is replaced by ingrowth of connective tissue that has properties similar to dura. ${ }^{34}$

Decompressive craniectomy is not an esthetic operation. The patient's scalp contours are disfigured for a period of months. In many patients, asymmetric cerebral 

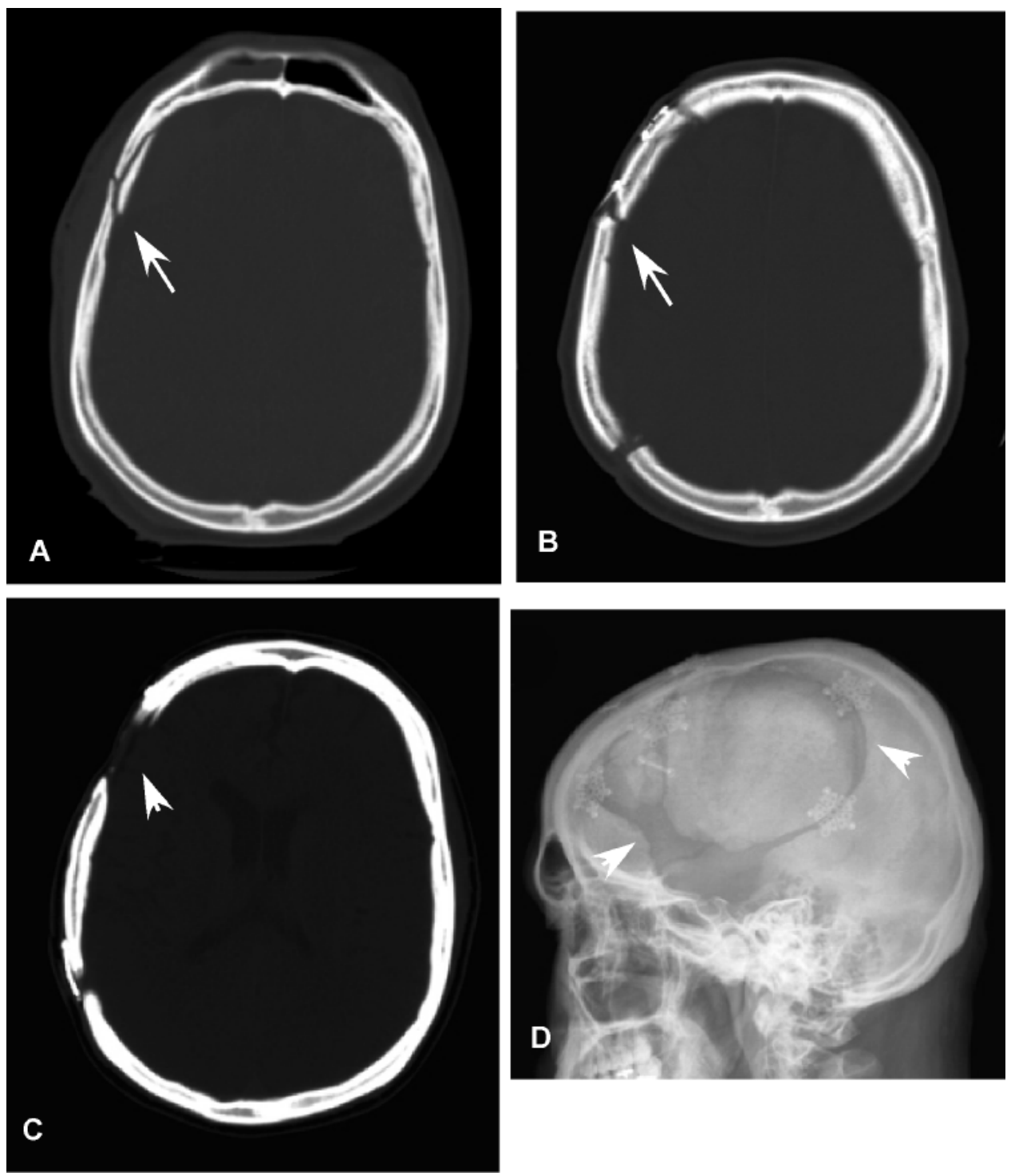

FIG. 9. Bone resorption. A: Noncontrast CT image of a frontal skull fracture (arrow) in a patient who underwent decompressive craniectomy. B: At 4 months following the decompressive surgery, an autologous cranioplasty repair was performed with plate reconstruction of his skull fracture (arrow). C and D: Noncontrast CT scan (C) and lateral plain skull film (D) obtained 2 months after the cranioplasty demonstrating extensive bone resorption of the fractured segment (arrowheads). The patient underwent a second cranioplasty with a synthetic bone flap.

swelling in the early phases is followed later by markedly sunken scalp contours ipsilateral to the bone decompression (Fig. 7). Cerebral atrophy secondary to brain injury can exacerbate the degree of concavity. The temporalis muscle is detached and atrophies, which may limit the excursion of mouth opening and cause difficulty chewing. Masticatory function, however, does not seem to be significantly impaired. In 1 study, even after the temporalis muscle was excised, only 2 (25\%) of 8 patients experienced lateral deviation of the mandible on opening their mouths or had difficulties with eating. ${ }^{62}$

Hydrocephalus. Hydrocephalus and syndrome of the trephined are the most frequent complications of decompressive craniectomy beyond 1 month. Decompressive craniectomy has been identified as a risk factor for
CSF alterations and development of posttraumatic hydrocepalus. ${ }^{53}$ Hydrocephalus has been associated with poorer outcome following TBI. ${ }^{51}$ Relatively few patients require ventriculoperitoneal shunt treatment before the bone flap has been replaced. Ventriculoperitoneal shunt treatment of hydrocephalus in the setting of a large cranial defect may also risk neurological deterioration consistent with a paradoxical herniation phenomenon. ${ }^{47}$

Syndrome of the Trephined. Syndrome of the trephined is a frequent, delayed complication of decompressive craniectomy. ${ }^{30}$ Common symptoms include headaches, dizziness, irritability, concentration difficulty, memory problems, and mood disturbances, which typically arise weeks to months following decompressive craniectomy. The diagnosis is often overlooked, as many of these symptoms are also common sequelae to postconcussion and 


\section{Complications of decompressive craniectomy for TBI}

posttraumatic stress syndromes that accompany TBI.

Less commonly, syndrome of the trephined can present with delayed onset of new neurological deficits. We have observed a small cohort of patients who developed motor weakness of the contralateral hand and upper extremity months after their decompressive surgery. ${ }^{82}$ We termed this motor trephine syndrome in reference to Grant's initial description of syndrome of the trephined. ${ }^{81,82}$ These motor deficits evolve in an insidious and progressive manner in a limb that was otherwise normal and not affected by the injury. From a series of 170 consecutive patients with TBI who were treated with decompressive craniectomy, we studied 38 patients with long-term follow-up after cranioplasty repair. ${ }^{82}$ We found 10 patients $(26 \%)$ with motor trephine syndrome who developed delayed upper-extremity weakness a mean of 5 months following decompressive craniectomy. All experienced marked, rapid improvement of their weakness within a few days of cranioplasty repair with subsequent full motor recovery.

The pathophysiological mechanisms underlying syndrome of the trephined have been a subject of debated theories. ${ }^{19}$ Changes in atmospheric pressure, ${ }^{83}$ altered CSF circulation, ${ }^{20,24}$ and changes in $\mathrm{CBF}^{68,85}$ have all been proposed to explain the pathophysiology underlying the syndrome. In early studies, a sunken scalp was noted in many patients with syndrome of the trephined (Fig. 7). ${ }^{27,98}$ Recently we discovered a high incidence of CT scanning abnormalities in patients who developed motor trephine syndrome. ${ }^{82}$ Patients who developed motor trephine syndrome were significantly more likely to have demonstrated CSF subdural hygromas as well as frontal and temporal contusions on their early postoperative CT scans. At later time points, CT scans demonstrated areas of hypodensity consistent with evolving interstitial edema in the brain parenchyma. ${ }^{22}$ This form of extracellular edema was attributed to transependymal flow and accumulation of water and CSF in previously contused areas of parenchyma underlying the skull defect. The CT perfusion imaging studies in 2 patients demonstrated reduced CBF in these areas of edematous change. Rapid improvements in $\mathrm{CBF}$ and resolution of these hypodense areas on $\mathrm{CT}$ occurred within days of cranioplasty repair, simultaneous with dramatic recovery of motor function.

We have observed that motor trephine syndrome develops in the setting of decompressive craniectomy as a result of 2 predisposing requisite factors (Fig. 8) ${ }^{81,82}$ First, a contusion or other parenchymal injury imparts a lower threshold for fluid shifts into brain tissue. In the absence of an overlying skull, reduced resistance promotes fluid shifts into areas underlying the skull defect. Second, decompressive craniectomy impairs normal CSF circulation. Over time, impairments of CSF flow, decompensate beyond the phases of subdural hygroma collections and hydrocephalus. ${ }^{1,19,20}$ Decompensated CSF flow manifests at late time points with leakage of CSF and edema fluid into vulnerable areas of injured parenchyma underlying the skull defect. This process is akin to the development of transependymal edema as a late response in normalpressure hydrocephalus. ${ }^{40}$ Microcirculatory compromise ensues within the edematous parenchyma, thereby im- pairing CBF. The combination of decreased cerebral perfusion and interstitial edema initiates a delayed, slowly progressive motor deficit. Cranioplasty repair quickly normalizes interstitial pressure, CSF flow, transependymal fluid shifts, and CBF leading to rapid recovery of motor function.

Patients with decompressive craniectomy should have serial neurological assessments for syndrome of the trephined and complaints of weakness, particularly in activities such as writing and buttoning, which involve the small muscles of the hand. Motor testing of the contralateral upper extremity should focus attention on the grip and metacarpal extensor strength. The motor trephine syndrome deficits are reversible, and physiotherapy should be involved to prevent development of contractures that could impair long-term function. Early cranioplasty may be considered, noting that the risks of infection are high with early replacement of the autologous bone flap. ${ }^{98,99}$ However, Liang et al. ${ }^{46}$ have recently shown that titanium mesh cranioplasty can be performed as early as 5-8 weeks after decompressive craniectomy without untoward infectious complications.

Bone Resorption. In decompressive craniectomy, bone resorption of free bone flaps is common and may approach an incidence as high as 50\% in long-term followup (Figs. 7 and 9). ${ }^{31,38,66}$ Skull fractures identified at the time of the original decompression should raise concern for possible bone resorption following cranioplasty (Fig. 9). Multiple fragments should lead to consideration of an upfront synthetic cranioplasty repair. During cranioplasty repair, tight approximation of the free flap to a lengthy surface of the native craniectomy margin reduces bone resorption. In our experience, rigid plate and screw fixation that permits minimal movement of the flap also appears to be important. A modified craniectomy in which the bone flap is not removed but rather is hinged has been proposed.$^{74}$ In 25 patients, hinge craniotomy was observed to provide adequate decompression of ICP with only 1 infection, 1 cranial deformity, no complications of bone resorption, and no cases of syndrome of the trephined. ${ }^{74}$ Osteoclast inhibitors may also be used to prevent bone resorption in the future. ${ }^{92}$

Persistent Vegetative State. Decompressive craniectomy is very effective in ameliorating raised ICP as a life-saving measure. While decompressive craniectomy reduces mortality, it may fail to rescue neurological function from devastating injury incurred by either the primary impact or secondary damage that evolves during the early resuscitation period. Risks of survival with an outcome of a persistent vegetative state after decompressive craniectomy have been reported to range upwards of 15 to $20 \%$ in many series (Table 2). Concerns have been raised that decompressive craniectomy facilitates survival, in a persistent vegetative or minimally conscious state, for patients who would otherwise have died of cerebral herniation from raised ICP. ${ }^{88}$ Preoperative GCS scores < 6 , brainstem dysfunction, older age, and longer time to decompression have been reported to be associated with a higher risk of persistent vegetative outcome, but further study is needed to precisely delineate the role of these 
TABLE 2: Literature summary of outcome following decompressive craniectomy for TBI*

\begin{tabular}{|c|c|c|c|c|c|c|c|}
\hline \multirow[b]{2}{*}{ Authors \& Year } & \multirow[b]{2}{*}{$\begin{array}{c}\text { No. of } \\
\text { Patients }\end{array}$} & \multirow[b]{2}{*}{ Indication† } & \multirow[b]{2}{*}{ Follow-Up Time } & \multicolumn{4}{|c|}{ No. of Patients (\%) } \\
\hline & & & & Favorable & $\begin{array}{l}\text { Severe } \\
\text { Disability }\end{array}$ & $\begin{array}{l}\text { Persistent } \\
\text { Vegetative }\end{array}$ & Mortality \\
\hline Aarabi et al., 2006 & 50 & $\begin{array}{l}\text { primary }(20 \%) \& \\
\text { secondary }(80 \%)\end{array}$ & $3 \mathrm{mos}$ & $20(40)$ & $9(18)$ & $7(14)$ & $14(28)$ \\
\hline Albanese et al., 2003 & 40 & $\begin{array}{c}\text { primary }(68 \%) \& \text { sec- } \\
\text { ondary }(32 \%) \text { DC }\end{array}$ & 12 mos & $10(25)$ & $13(33)$ & $\begin{array}{c}\text { included w/ } \\
\text { severe disability }\end{array}$ & $17(43)$ \\
\hline $\begin{array}{l}\text { Chibbaro \& Tacconi, } \\
2007\end{array}$ & 48 & secondary DC & $\begin{array}{c}\text { mean } 14 \text { mos (range } \\
6-25 \text { mos) }\end{array}$ & $25(55)$ & $6(12)$ & $9(20)$ & $6(12)$ \\
\hline De Luca et al., 2000 & 22 & $\begin{array}{c}\text { primary \& secondary } \\
\text { DC }\end{array}$ & not specified & $9(41)$ & $4(18)$ & $5(23)$ & $4(18)$ \\
\hline Gaab et al., 1990 & 37 & secondary DC & $12 \mathrm{mos}$ & $14(38)$ & $12(32)$ & $3(8)$ & $5(13)$ \\
\hline Guerra et al., 1999 & 57 & $\begin{array}{c}\text { primary }(68 \%) \& \text { sec- } \\
\text { ondary }(32 \%) \text { DC }\end{array}$ & $12 \mathrm{mos}$ & $33(58)$ & $6(11)$ & $5(9)$ & $11(19)$ \\
\hline Howard et al., 2008 & 40 & $\begin{array}{c}\text { primary }(60 \%) \& \text { sec- } \\
\text { ondary }(40 \%) \text { DC }\end{array}$ & $\begin{array}{c}\text { 3-26 mos } \\
\text { (mean } 11 \text { mos) }\end{array}$ & $\begin{array}{c}\text { 12/18 survivors } \\
(67 \%), 12 / 40 \\
(30 \%) \text { overall }\end{array}$ & $6 / 40(15)$ & $\begin{array}{c}\text { included w/ } \\
\text { severe disability }\end{array}$ & $22 / 40(55)$ \\
\hline Huang et al., 2008 & 38 & primary DC & $>6 \mathrm{mos}$ & $29(76)$ & $2(5)$ & $2(5)$ & $5(13)$ \\
\hline Jiang et al., 2005 & 241 & primary DC & $6 \mathrm{mos}$ & $96(40)$ & $71(30)$ & $9(4)$ & $63(26)$ \\
\hline Kunze et al., 1998 & 28 & secondary DC & $12 \mathrm{mos}$ & $15(56)$ & $5(18)$ & $4(14)$ & $3(11)$ \\
\hline Meier et al., 2006 & 117 & $\begin{array}{l}\text { primary }(63 \%) \& \\
\text { secondary (37\%) }\end{array}$ & not specified & $30(26)$ & $24(20)$ & $16(14)$ & $47(40)$ \\
\hline Morgalla et al., 2008 & 33 & $\begin{array}{c}\text { primary }(27 \%) \& \text { sec- } \\
\text { ondary }(73 \%) \text { DC }\end{array}$ & $3 \mathrm{yrs}$ & $13(40)$ & $8(24)$ & $7(20)$ & $7(20)$ \\
\hline Munch et al., 2000 & 49 & $\begin{array}{c}\text { primary }(63 \%) \& \text { sec- } \\
\text { ondary }(37 \%) \text { DC }\end{array}$ & $6 \mathrm{mos}$ & $20 \%$ & $33 \%$ & $14 \%$ & $33 \%$ \\
\hline Olivecrona et al., 2007 & 21 & secondary DC & not specified & $15(71)$ & $2(10)$ & $1(5)$ & $3(14)$ \\
\hline Polin et al., 1997 & 35 & $\begin{array}{l}\text { secondary bifrontal } \\
\text { DC, pediatric }\end{array}$ & $\begin{array}{l}\text { at discharge (mean } \\
63 \text { days, range } \\
10-220 \text { days) }\end{array}$ & $13(37)$ & $11(31)$ & $3(9)$ & $8(23)$ \\
\hline Schneider et al., 2002 & 62 & secondary DC & $6 \mathrm{mos}$ & $18(29)$ & $30(48)$ & $0(0)$ & $14(23)$ \\
\hline Skoglund et al., 2006 & 19 & $\begin{array}{c}\text { primary }(11 \%) \text { \& sec- } \\
\text { ondary }(89 \%) \text { DC }\end{array}$ & $\begin{array}{c}\min 12 \text { mos } \\
\text { (range } 1-6 \text { yrs) }\end{array}$ & $13(68)$ & $3(16)$ & $1(5)$ & $2(11)$ \\
\hline Timofeev et al., 2006 & 49 & secondary DC & $6 \mathrm{mos}$ & $30(61)$ & $10(21)$ & $0(0)$ & $9(18)$ \\
\hline Whitfield et al., 2001 & 26 & secondary DC & $\begin{array}{c}>6 \text { mos } \\
\text { (mean } 10 \text { mos) }\end{array}$ & $18(69)$ & $2(8)$ & $0(0)$ & $6(23)$ \\
\hline
\end{tabular}

* DC = decompressive craniectomy.

$\dagger$ Primary decompressive craniectomies were performed for up-front surgical decompression. Secondary delayed decompressive craniectomies were performed for raised ICP refractory to medical management.

factors in the risk-benefit analysis guiding operative decisions. ${ }^{3,91}$

\section{Complication Avoidance}

In treating patients who have sustained TBI, the neurosurgeon needs to carefully judge those who will benefit from immediate decompressive craniectomy and those who are best treated by initial monitoring and medical treatment of intracranial hypertension. Careful patient selection for decompressive craniectomy is needed to guard against a heroic intervention that increases survival at the expense of a persistent vegetative outcome. At surgery, a wide bone decompression should be performed and the dura opened. To minimize risk of wound dehiscence and infection, care should be made to preserve the superficial temporal artery and to ensure a scalp flap with a wide base-to-pedicle ratio. In addition, support beneath the myocutaneous scalp flap as it is reflected forward prevents acute angulation and impaired perfusion of the scalp pedicle. The frontal bone decompression should avoid opening into the frontal sinus. Augmentation of the craniectomy with a duraplasty has been suggested as a mechanism to prevent or limit external cerebral herniation. ${ }^{99}$ Others have devised vascular cushions tunneled along the vessels at the bone edge to protect the veins from obstructive pressure. ${ }^{16,17}$ The dura should be opened in a manner such that large veins at the bone edge are not situated at the apex of the dural slits. ${ }^{17}$ Techniques of a lat- 


\section{Complications of decompressive craniectomy for TBI}

tice duraplasty have also been suggested to limit external cerebral herniation. ${ }^{55}$

The presence of a skull fracture contralateral to the craniectomy should prompt consideration for an immediate or very early postoperative CT scan to rule out development of a mass lesion underlying the fracture. ${ }^{84}$ If possible, tapping and shunt treatment of CSF subdural hygromas should be avoided. They almost always resolve over time on their own. Lumbar puncture carries a risk of paradoxical herniation at the time of puncture and even months later.

Hydrocephalus is a delayed complication of decompressive craniectomy. Few decompressed skulls require shunt treatment. Ventriculoperitoneal shunt treatment in patients with a skull defect can also risk paradoxical herniation. In many cases cranioplasty repair of the skull defect may normalize the impaired CSF flow and obviate the need for a shunt. The patient's neurological examination should be followed closely with particular attention for signs and symptoms of syndrome of the trephined.

\section{Conclusions}

Decompressive craniectomy is viewed by many as a simple surgical procedure, yet complications may be as common as those associated with complex skull base surgery. High mortality rates relate primarily to the severity of the trauma for which the operation is performed. Factors important in patient selection need to be further studied and refined to ensure the highest chances of favorable outcome. Many complications of decompressive craniectomy are inherent in the pathophysiological processes that ensue following removal of a large portion of skull bone. Other complications, including high rates of infection, derive from the technical aspects of the surgery including large scalp incisions, need for bone storage, and the challenges of sterility accompanying the nature of trauma surgery.

Different types of complications occur in discrete temporal windows. Changes in interstitial pressures and brain compliance, CSF circulation, CBF, and cerebral vasoreactivity and autoregulation play a role in early postoperative complications of contusion blossoming, external cerebral herniation, and formation of contralateral extraaxial hematomas. During the first weeks following decompression, subdural hygromas arise secondary to alterations in brain compliance and CSF circulation. Rare paradoxical herniation syndromes highlight the abnormal pressure dynamics across the cranial-spinal compartments following decompression.

In the late phases following decompression, syndrome of the trephined may lead to cognitive, psychological, and neurological deficits. Patients may develop a motor trephine deficit, typically a new, delayed-onset motor deficit of the contralateral upper extremity. We postulate that these motor trephine deficits arise from development of interstitial edema in areas of contused and injured brain underlying the skull defect. Motor trephine syndrome deficits are rapidly and completely reversed following cranioplasty repair. Further studies are needed to advance our understanding of the pathophysiological processes following decompressive craniectomy to obviate complications and provide patients with TBI with the best possible outcomes from this surgery.

\section{Disclaimer}

The author reports no conflict of interest concerning the materials or methods used in this study or the findings specified in this paper.

\section{References}

1. Aarabi B, Hesdorffer DC, Ahn ES, Aresco C, Scalea TM, Eisenberg HM: Outcome following decompressive craniectomy for malignant swelling due to severe head injury. J Neurosurg 104:469-479, 2006

2. Abdullah J,Zamzuri I, Awang S, Sayuthi S, Ghani A, Tahir A, et al: Preliminary report on spiegelberg pre and post-operative monitoring of severe head-injured patients who received decompressive craniectomy. Acta Neurochir Suppl 95:311-314, 2005

3. Albanese J, Leone M, Alliez JR, Kaya JM, Antonini F, Alliez B, et al: Decompressive craniectomy for severe traumatic brain injury: evaluation of the effects at one year. Crit Care Med 31:2535-2538, 2003

4. Bernstein M, Fleming JFR, Deck JHN: Cerebral hyperperfusion after carotid endarterectomy: a cause of cerebral hemorrhage. Neurosurgery 15:50-56, 1984

5. Binder DK, Dillon WP, Fishman RA, Schmidt MH: Intrathecal saline infusion in the treatment of obtundation associated with spontaneous intracranial hypotension: technical case report. Neurosurgery 51:830-837, 2002

6. Bloch J, Regli L: Brain stem and cerebellar dysfunction after lumbar spinal fluid drainage: case report. J Neurol Neurosurg Psychiatry 74:992-994, 2003

7. Bor-Seng-Shu E, Hirsch R, Teixeira MJ, De Andrade AF, Marino R Jr: Cerebral hemodynamic changes gauged by transcranial Doppler ultrasonography in patients with posttraumatic brain swelling treated by surgical decompression. $\mathbf{J}$ Neurosurg 104:93-100, 2006

8. Borovich B, Braun J, Guilburd JN, Zaaroor M, Michich M, Levy L, et al: Delayed onset of traumatic extradural hematoma. J Neurosurg 63:30-34, 1985

9. Carvi Y, Nievas MN, Hollerhage HG: Early combined cranioplasty and programmable shunt in patients with skull bone defects and CSF-circulation disorders. Neurol Res 28:139-144, 2006

10. Chang EF, Meeker M, Holland MC: Acute traumatic intraparenchymal hemorrhage: risk factors for progression in the early post-injury period. Neurosurgery 58:647-656, 2006

11. Chibbaro S, Tacconi L: Role of decompressive craniectomy in the management of severe head injury with refractory cerebral edema and intractable intracranial pressure. Our experience with 48 cases. Surg Neurol 68:632-638, 2007

12. Chieregato A, Fainardi E, Morselli-Labate AM, Antonelli V, Compagnone C, Targa L, et al: Factors associated with neurological outcome and lesion progression in traumatic subarachnoid hemorrhage patients. Neurosurgery 56:671-680, 2005

13. Cohen JE, Rajz G, Itshayek E, Umansky F: Bilateral acute epidural hematoma after evacuation of acute subdural hematoma: brain shift and the dynamics of extraaxial collections. Neurol Res 26:763-766, 2004

14. Cooper DJ, Rosenfeld JV, Murray L, Wolfe R, Ponsford J, Davies A, et al: Early decompressive craniectomy for patients with severe traumatic brain injury and refractory intracranial hypertension-a pilot randomized trial. J Crit Care 23:387393, 2008

15. Cooper PR, Hagler H, Clark WK, Barnett P: Enhancement of experimental cerebral edema after decompressive craniecto- 
my: implications for the management of severe head injuries. Neurosurgery 4:296-300, 1979

16. Csokay A, Nagy L, Novoth B: Avoidance of vascular compression in decompressive surgery for brain edema caused by trauma and tumor ablation. Neurosurg Rev 24:209-213, 2001

17. Csokay A, Nagy L, Pentelenvi T: "Vascular tunnel" formation to improve the effect of decompressive craniectomy in the treatment of brain swelling caused by trauma and hypoxia. Acta Neurochir (Wien) 143:173-175, 2001

18. De Luca GP, Volpin L, Fornezza U, Cervellini P, Zanusso M, Casentini L, et al: The role of decompressive craniectomy in the treatment of uncontrollable post-traumatic intracranial hypertension. Acta Neurochir Suppl 76:401-404, 2000

19. Dujovny M, Agner C, Aviles A: Syndrome of the trephined: theory and facts. Crit Rev Neurosurg 9:271-278, 1999

20. Dujovny M, Fernandez P, Alperin N, Betz W, Misra M, Mafee M: Post-cranioplasty cerebrospinal fluid hydrodynamic changes: magnetic resonance imaging quantitative analysis. Neurol Res 19:311-316, 1997

21. Fields JD, Lansberg MG, Skirboll SL, Kurien PA, Wijman CA: "Paradoxical" transtentorial herniation due to CSF drainage in the presence of a hemicraniectomy. Neurology 67:1513-1514, 2006

22. Fishman RA: Cerebrospinal Fluid Disease of the Nervous System. Philadelphia: W.B. Saunders, 1980

23. Flint AC, Manley GT, Gean AD, Hemphill JC III, Rosenthal G: Post-operative expansion of hemorrhagic contusions after unilateral decompressive hemicraniectomy in severe traumatic brain injury. J Neurotrauma 25:503-512, 2008

24. Fodstad H, Love JA, Ekstedt J, Friden H, Liliequist B: Effect of cranioplasty on cerebrospinal fluid hydrodynamics in patients with the syndrome of the trephined. Acta Neurochir (Wien) 70:21-30, 1984

25. Gaab M, Knoblich OE, Fuhrmeister U, Pflughaupt KW, Dietrich K: Comparison of the effects of surgical decompression and resection of local edema in the therapy of experimental brain trauma. Investigation of ICP, EEG and cerebral metabolism in cats. Childs Brain 5:484-498, 1979

26. Gaab MR, Rittierodt M, Lorenz M, Heissler HE: Traumatic brain swelling and operative decompression: a prospective investigation. Acta Neurochir Suppl (Wien) 51:326-328, 1990

27. George AE, Morantz RA, Abad RM, Rovit RL, Chase N: Neuroradiology of the posthemicraniectomy patient with special emphasis on the radiology of unilateral atrophy. Radiology 111:627-631, 1974

28. Givner A, Gurney J, O'Connor D, Kassarjian A, Lamorte WW, Moulton S: Reimaging in pediatric neurotrauma: factors associated with progression of intracranial injury. J Pediatr Surg 37:381-385, 2002

29. Grande PO, Asgeirsson B, Nordstrom CH: Physiologic principles for volume regulation of a tissue enclosed in a rigid shell with application to the injured brain. J Trauma 42:S23-S31, 1997

30. Grant F, Norcross N: Repair of cranial defects by cranioplasty. Ann Surg 110:488-512, 1939

31. Grant GA, Jolley M, Ellenbogen RG, Roberts TS, Gruss JR, Loeser JD: Failure of autologous bone-assisted cranioplasty following decompressive craniectomy in children and adolescents. J Neurosurg 100:163-168, 2004

32. Guerra WK, Gaab MR, Dietz H, Mueller JU, Piek J, Fritsch MJ: Surgical decompression for traumatic brain swelling: indications and results. J Neurosurg 90:187-196, 1999

33. Hase U, Reulen HJ, Meinig G, Schurmann K: The influence of the decompressive operation on the intracranial pressure and the pressure-volume relation in patients with severe head injuries. Acta Neurochir (Wien) 45:1-13, 1978

34. Horaczek JA, Zierski J, Graewe A: Collagen matrix in de- compressive hemicraniectomy. Neurosurgery 63:ONS176ONS181, 2008

35. Howard JL, Cipolle MD, Anderson M, Sabella V, Shollenberger D, Li PM, et al: Outcome after decompressive craniectomy for the treatment of severe traumatic brain injury. J Trauma 65:380-386, 2008

36. Huang AP, Tu YK, Tsai YH, Chen YS, Hong WC, Yang CC, et al: Decompressive craniectomy as the primary surgical intervention for hemorrhagic contusion. J Neurotrauma 25:13471354,2008

37. Hutchinson PJ, Corteen E, Czosnyka M, Mendelow AD, Menon DK, Mitchell P, et al: Decompressive craniectomy in traumatic brain injury: the randomized multicenter RESCUEicp study (www.RESCUEicp.com). Acta Neurochir Suppl 96:17-20, 2006

38. Iwama T, Yamada J, Imai S, Shinoda J, Funakoshi T, Sakai N: The use of frozen autogenous bone flaps in delayed cranioplasty revisited. Neurosurgery 52:591-596, 2003

39. Jaeger M, Soehle M, Meixensberger J: Effects of decompressive craniectomy on brain tissue oxygen in patients with intracranial hypertension. J Neurol Neurosurg Psychiatry 74:513-515, 2003

40. James AE Jr, Strecker EP, Sperber E, Flor WJ, Merz T, Burns B: An alternative pathway of cerebrospinal fluid absorption in communicating hydrocephalus. Transependymal movement. Radiology 111:143-146, 1974

41. Jiang JY, Xu W, Li WP, Xu WH, Zhang J, Bao YH, et al: Efficacy of standard trauma craniectomy for refractory intracranial hypertension with severe traumatic brain injury: a multicenter, prospective, randomized controlled study. J Neurotrauma 22:623-628, 2005

42. Komotar RJ, Mocco J, Ransom ER, Mack WJ, Zacharia BE, Wilson DA, et al: Herniation secondary to critical postcraniotomy cerebrospinal fluid hypovolemia. Neurosurgery $\mathbf{5 7 : 2 8 6 - 2 9 2 , 2 0 0 5}$

43. Konig A, Laas R, Herrmann HD: Cerebellar haemorrhage as a complication after supratentorial craniotomy. Acta Neurochir (Wien) 88:104-108, 1987

44. Kunze E, Meixensberger J, Janka M, Sorensen N, Roosen K: Decompressive craniectomy in patients with uncontrollable intracranial hypertension. Acta Neurochir Suppl 71:16-18, 1998

45. Lang JK, Ludwig HC, Mursch K, Zimmerer B, Markakis E: Elevated cerebral perfusion pressure and low colloid osmotic pressure as a risk factor for subdural space-occupying hygromas? Surg Neurol 52:630-637, 1999

46. Liang W, Xiaofeng Y, Weiguo L, Gang S, Xuesheng Z, Fei $\mathrm{C}$, et al: Cranioplasty of large cranial defect at an early stage after decompressive craniectomy performed for severe head trauma. J Craniofac Surg 18:526-532, 2007

47. Liao CC, Kao MC: Cranioplasty for patients with severe depressed skull bone defect after cerebrospinal fluid shunting. J Clin Neurosci 9:553-555, 2002

48. Maas AI, Hukkelhoven CW, Marshall LF, Steyerberg EW: Prediction of outcome in traumatic brain injury with computed tomographic characteristics: a comparison between the computed tomographic classification and combinations of computed tomographic predictors. Neurosurgery 57:11731182,2005

49. Makino H, Yamaura A: Assessment of outcome following large decompressive craniectomy in management of serious cerebral contusion. A review of 207 cases. Acta Neurochir Suppl (Wien) 28:193-194, 1979

50. Malliti M, Page P, Gury C, Chomette E, Nataf F, Roux FX: Comparison of deep wound infection rates using a synthetic dural substitute (neuro-patch) or pericranium graft for dural closure: a clinical review of 1 year. Neurosurgery 54:599603, 2004

51. Marmarou A, Foda MA, Bandoh K, Yoshihara M, Yamamoto 


\section{Complications of decompressive craniectomy for TBI}

T, Tsuji O, et al: Posttraumatic ventriculomegaly: hydrocephalus or atrophy? A new approach for diagnosis using CSF dynamics. J Neurosurg 85:1026-1035, 1996

52. Matsuno A, Katayama H, Wada H, Morikawa K, Tanaka K, Tanaka H, et al: Significance of consecutive bilateral surgeries for patients with acute subdural hematoma who develop contralateral acute epi- or subdural hematoma. Surg Neurol 60:23-30, 2003

53. Mazzini L, Campini R, Angelino E, Rognone F, Pastore I, Oliveri G: Posttraumatic hydrocephalus: a clinical, neuroradiologic, and neuropsychologic assessment of long-term outcome. Arch Phys Med Rehabil 84:1637-1641, 2003

54. Meier U, Lemcke J, Reyer T, Grawe A: Decompressive craniectomy for severe head injury in patients with major extracranial injuries. Acta Neurochir Suppl 96:373-376, 2006

55. Mitchell P, Tseng M, Mendelow AD: Decompressive craniectomy with lattice duraplasty. Acta Neurochir (Wien) 146:159-160, 2004

56. Morgalla MH, Will BE, Roser F, Tatagiba M: Do long-term results justify decompressive craniectomy after severe traumatic brain injury? J Neurosurg 109:685-690, 2008

57. Munch E, Horn P, Schurer L, Piepgras A, Paul T, Schmiedek $P$ : Management of severe traumatic brain injury by decompressive craniectomy. Neurosurgery 47:315-322, 2000

58. Oertel M, Kelly DF, McArthur D, Boscardin WJ, Glenn TC, Lee JH, et al: Progressive hemorrhage after head trauma: predictors and consequences of the evolving injury. J Neurosurg 96:109-116, 2002

59. Olivecrona M, Rodling-Wahlstrom M, Naredi S, Koskinen LO: Effective ICP reduction by decompressive craniectomy in patients with severe traumatic brain injury treated by an ICP-targeted therapy. J Neurotrauma 24:927-935, 2007

60. Osawa M, Hara H, Ichinose Y, Koyama T, Kobayashi S, Sugita Y: Cranioplasty with a frozen and autoclaved bone flap. Acta Neurochir (Wien) 102:38-41, 1990

61. Oyelese AA, Steinberg GK, Huhn SL, Wijman CA: Paradoxical cerebral herniation secondary to lumbar puncture after decompressive craniectomy for a large space-occupying hemispheric stroke: case report. Neurosurgery 57:E594, 2005

62. Park J, Kim E, Kim GJ, Hur YK, Guthikonda M: External decompressive craniectomy including resection of temporal muscle and fascia in malignant hemispheric infarction. J Neurosurg 110:101-105, 2009

63. Piepmeier JM, Wagner FC Jr: Delayed post-traumatic extracerebral hematomas. J Trauma 22:455-460, 1982

64. Plesnila N: Decompression craniectomy after traumatic brain injury: recent experimental results. Prog Brain Res 161:393400, 2007

65. Polin RS, Shaffrey ME, Bogaev CA, Tisdale N, Germanson $\mathrm{T}$, Bocchicchio B, et al: Decompressive bifrontal craniectomy in the treatment of severe refractory posttraumatic cerebral edema. Neurosurgery 41:84-92, 1997

66. Posnick JC, Goldstein JA, Armstrong D, Rutka JT: Reconstruction of skull defects in children and adolescents by the use of fixed cranial bone grafts: long-term results. Neurosurgery 32:785-791, 1993

67. Rasmussen S, Ohrstrom JK, Westergaard L, Kosteljanetz M: Post-operative infections of osteoplastic compared with free bone flaps. Br J Neurosurg 4:493-495, 1990

68. Richaud J, Boetto S, Guell A, Lazorthes Y: Effects of cranioplasty on neurological function and cerebral blood flow. Neurochirurgie 31:183-188, 1985

69. Rinaldi A, Mangiola A, Anile C, Maira G, Amante P, Ferraresi A: Hemodynamic effects of decompressive craniectomy in cold induced brain oedema. Acta Neurochir Suppl (Wien) 51:394-396, 1990

70. Sahuquillo J, Arikan F: Decompressive craniectomy for the treatment of refractory high intracranial pressure in traumat- ic brain injury. Cochrane Database Syst Rev: CD003983, 2006

71. Sakaki T, Tsujimoto S, Nishitani M, Ishida Y, Morimoto T: Perfusion pressure breakthrough threshold of cerebral autoregulation in the chronically ischemic brain: an experimental study in cats. J Neurosurg 76:478-485, 1992

72. Samadani U, Huang JH, Baranov D, Zager EL, Grady MS: Intracranial hypotension after intraoperative lumbar cerebrospinal fluid drainage. Neurosurgery 52:148-151, 2003

73. Schievink WI: Spontaneous spinal cerebrospinal fluid leaks and intracranial hypotension. JAMA 295:2286-2296, 2006

74. Schmidt JH III, Reyes BJ, Fischer R, Flaherty SK: Use of hinge craniotomy for cerebral decompression. Technical note. J Neurosurg 107:678-682, 2007

75. Schneider GH, Bardt T, Lanksch WR, Unterberg A: Decompressive craniectomy following traumatic brain injury: ICP, CPP and neurological outcome. Acta Neurochir Suppl 81:77-79, 2002

76. Schwab S, Erbguth F, Aschoff A, Orberk E, Spranger M, Hacke W: ["Paradoxical" herniation after decompressive trephining.] Nervenarzt 69:896-900, 1998 (Ger)

77. Servadei F, Nanni A, Nasi MT, Zappi D, Vergoni G, Giuliani $\mathrm{G}$, et al: Evolving brain lesions in the first 12 hours after head injury: analysis of 37 comatose patients. Neurosurgery 37:899-906, 1995

78. Skoglund TS, Eriksson-Ritzen C, Jensen C, Rydenhag B: Aspects on decompressive craniectomy in patients with traumatic head injuries. J Neurotrauma 23:1502-1509, 2006

79. Smith JS, Chang EF, Rosenthal G, Meeker M, von Koch C, Manley GT, et al: The role of early follow-up computed tomography imaging in the management of traumatic brain injury patients with intracranial hemorrhage. J Trauma 63:7582, 2007

80. Stiefel MF, Heuer GG, Smith MJ, Bloom S, Maloney-Wilensky E, Gracias VH, et al: Cerebral oxygenation following decompressive hemicraniectomy for the treatment of refractory intracranial hypertension. J Neurosurg 101:241-247, 2004

81. Stiver SI, Wintermark M, Manley GT: Motor trephine syndrome: a mechanistic hypothesis. Acta Neurochir Suppl 102:273-277, 2008

82. Stiver SI, Wintermark M, Manley GT: Reversible monoparesis following decompressive hemicraniectomy for traumatic brain injury. J Neurosurg 109:245-254, 2008

83. Stula D: Intracranial pressure measurement in large skull defects. Neurochirurgia (Stuttg) 28:164-169, 1985

84. Su TM, Lee TH, Chen WF, Lee TC, Cheng CH: Contralateral acute epidural hematoma after decompressive surgery of acute subdural hematoma: clinical features and outcome. J Trauma 65:1298-1302, 2008

85. Suzuki N, Suzuki S, Iwabuchi T: Neurological improvement after cranioplasty. Analysis by dynamic CT scan. Acta Neurochir (Wien) 122:49-53, 1993

86. Thibodeau M, Melanson D, Ethier R: Acute epidural hematoma following decompressive surgery of a subdural hematoma. Can Assoc Radiol J 38:52-53, 1987

87. Timofeev I, Czosnyka M, Nortje J, Smielewski P, Kirkpatrick P, Gupta A, et al: Effect of decompressive craniectomy on intracranial pressure and cerebrospinal compensation following traumatic brain injury. J Neurosurg 108:66-73, 2008

88. Timofeev I, Hutchinson PJ: Outcome after surgical decompression of severe traumatic brain injury. Injury 37:11251132,2006

89. Timofeev I, Kirkpatrick PJ, Corteen E, Hiler M, Czosnyka M, Menon DK, et al: Decompressive craniectomy in traumatic brain injury: outcome following protocol-driven therapy. Acta Neurochir Suppl 96:11-16, 2006

90. Tokoro K, Chiba Y, Tsubone K: Late infection after cra- 
nioplasty-review of 14 cases. Neurol Med Chir (Tokyo) 29:196-201, 1989

91. Ucar T, Akyuz M, Kazan S, Tuncer R: Role of decompressive surgery in the management of severe head injuries: prognostic factors and patient selection. J Neurotrauma 22:1311-1318, 2005

92. Vaananen K: Mechanism of osteoclast mediated bone resorption-rationale for the design of new therapeutics. Adv Drug Deliv Rev 57:959-971, 2005

93. Vilela MD: Delayed paradoxical herniation after a decompressive craniectomy: case report. Surg Neurol 69:293-296, 2008

94. Wang EC, Ang BT, Wong J, Lim J, Ng I: Characterization of cerebrovascular reactivity after craniectomy for acute brain injury. Br J Neurosurg 20:24-30, 2006

95. Whitfield PC, Patel H, Hutchinson PJ, Czosnyka M, Parry D, Menon D, et al: Bifrontal decompressive craniectomy in the management of posttraumatic intracranial hypertension. Br J Neurosurg 15:500-507, 2001

96. Yamakami I, Yamaura A: Effects of decompressive craniectomy on regional cerebral blood flow in severe head trauma patients. Neurol Med Chir (Tokyo) 33:616-620, 1993

97. Yamakami I, Yamaura A, Isobe K: Types of traumatic brain injury and regional cerebral blood flow assessed by $99 \mathrm{mTc}-$ HMPAO SPECT. Neurol Med Chir (Tokyo) 33:7-12, 1993

98. Yamaura A, Sato M, Meguro K, Nakamura T, Uemura K: Cranioplasty following decompressive craniectomy-analysis of 300 cases. No Shinkei Geka 5:345-353, 1977
99. Yang XF, Wen L, Shen F, Li G, Lou R, Liu WG, et al: Surgical complications secondary to decompressive craniectomy in patients with a head injury: a series of 108 consecutive cases. Acta Neurochir (Wien) 150:1241-1248, 2008

100. Yang XJ, Hong GL, Su SB, Yang SY: Complications induced by decompressive craniectomies after traumatic brain injury. Chin J Traumatol 6:99-103, 2003

101. Yoshida K, Furuse M, Izawa A, Iizima N, Kuchiwaki H, Inao $\mathrm{S}$ : Dynamics of cerebral blood flow and metabolism in patients with cranioplasty as evaluated by $133 \mathrm{Xe} \mathrm{CT}$ and $31 \mathrm{P}$ magnetic resonance spectroscopy. J Neurol Neurosurg Psychiatry 61:166-171, 1996

102. Zweckberger K, Stoffel M, Baethmann A, Plesnila N: Effect of decompression craniotomy on increase of contusion volume and functional outcome after controlled cortical impact in mice. J Neurotrauma 20:1307-1314, 2003

Manuscript submitted February 15, 2009.

Accepted April 1, 2009.

Address correspondence to: Shirley Stiver, M.D., Ph.D., San Francisco General Hospital, 1001 Potrero Avenue, Building 1, Room 101, San Francisco, California 94110-0899. email: sstiver@ neurosurg.ucsf.edu. 